\title{
THE ELECTRONIC DATABASE OF FLORA OF THE SOUTH-EAST KYZYL-KUM RELICS
}

\author{
A.Batoshov \\ Namangan state university \\ N.Noralieva \\ Andijan state university \\ N.Sidiqjanov \\ Andijan state university \\ A.Turgunboev \\ Andijan state university
}

Article DOI: $\underline{\text { https://doi.org/10.36713/epra4103 }}$

\begin{abstract}
In last years, in floristic investigations, more attention has been paid to the formation of the electronic databases. In Uzbekistan, this tendency is associated with the research of K.Sh. Tojibayev (Database, 2010), where a database of large natural flora was compiled for the first time in Central Asia. In subsequent years, the accumulation of floristic data in the form of an electronic database has become one of the mandatory components. In particular, special attention was paid to this in the work of F.I. Karimov on monocotyledonous geophytes of the Ferghana Valley (Karimov, 2015)
\end{abstract}

\section{DISCUSSION}

In last years, in floristic investigations, more attention has been paid to the formation of the electronic databases. In Uzbekistan, this tendency is associated with the research of K.Sh. Tojibayev (Database, 2010), where a database of large natural flora was compiled for the first time in Central Asia. In subsequent years, the accumulation of floristic data in the form of an electronic database has become one of the mandatory components. In particular, special attention was paid to this in the work of F.I. Karimov on monocotyledonous geophytes of the Ferghana Valley (Karimov, 2015)

The foundation of the database is all the available information: printed sources on plant diversity of the research area, SRI reports and TASH herbarium materials. For formation of the database, it was necessary to compile all the information (about taxonomy, morphology, ecology, geographical distribution, economic importance and the status of the rarity of species) into a single information environment in the form of a database. Since 1913 (first expedition of M.V. Kultiasov in Pistalitau), little material has been accumulated. In the process of preparing the dissertation, we involved all the data stored in TASH, and the results of research projects carried out in various institutions of Uzbekistan

Basic matrix for data accumulating on the distribution of plant species is the developed scheme of botanical and geographical zoning of Uzbekistan (Tojibayev, 2012). This scheme is based on the naturalness of the boundaries of the regions, an analysis of the originality of the floristic composition, distribution of endemic and subendemic taxa, an analysis of the geographical relationships of various taxa, landscape features and plant cover.

The database is intended for the presentation of information and analytical information about the flora of the relics of Southeast Kyzylkum.

Functional properties of the database:

- $\quad$ it is given a detailed description of plant species;

- $\quad$ it is possible viewing geographical coordinates and a distribution map of species; 


\section{EPRA International Journal of Research and Development (IJRD)}

Volume: 5 | Issue: 3 | March 2020

- Peer Reviewed Journal

scanned images of herbarium and photographs of species in nature are presented;

species are noted included in the Red Book of the Republic of Uzbekistan;

it is possible search for species by identification numbers and names;

it is reflected information about collectors and identifiers;

it was ensured loading of the abstract of the flora of the relics of Southeast Kyzylkum (Batoshov, 2016).

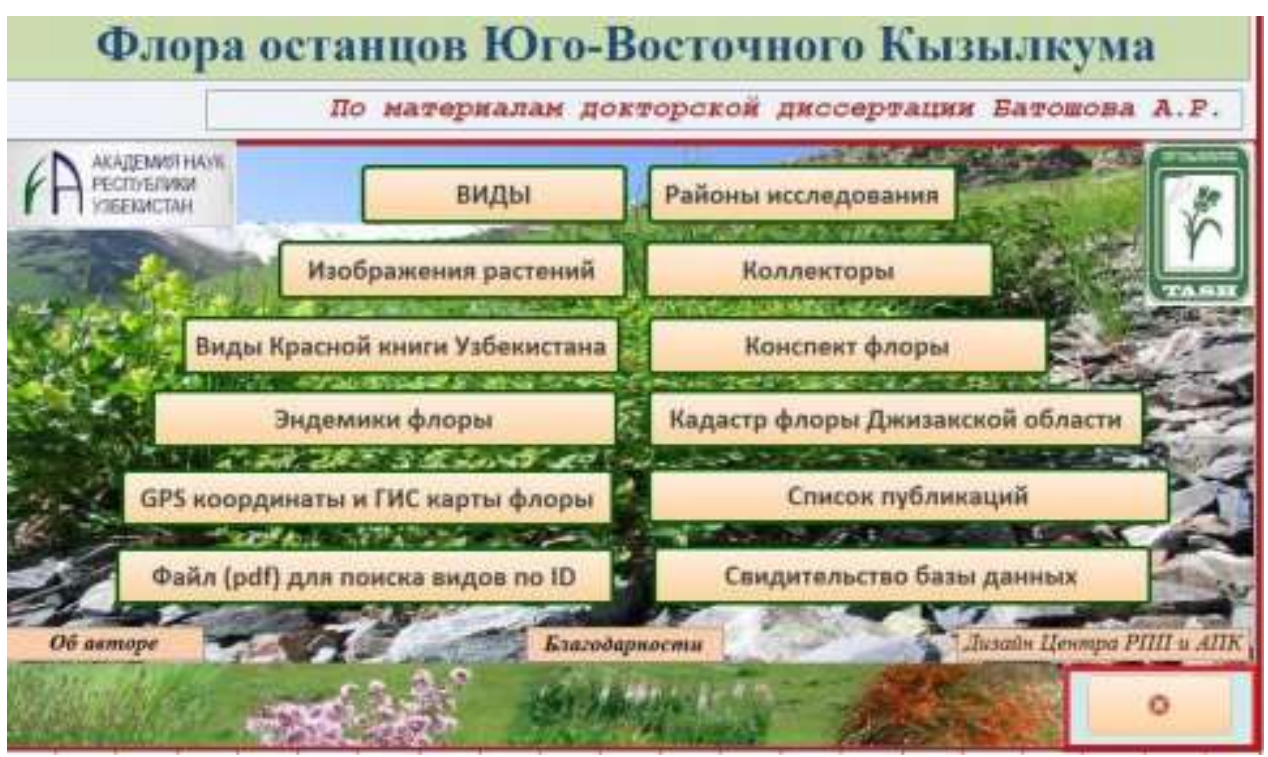

Fig. 1.1. Database Cover Page

The next page of the database opens with the text VIEWS. For each species, information is provided on 15 parameters (Fig. 1.2). These parameters combine information on the taxonomic affiliation of the species (family, genus, and species), nomenclature (sources of
Below information is given on detailed structure and functionality of the database on the flora of the relics of Southeast Kyzylkum. The database consists of 11 sections (windows): types, images, species of the Red Book of the Republic of Uzbekistan, endemic flora, GPS coordinates of collections by species and GIS map, information about the research area, collectors, data on the cadastral flora of vascular plants of Jizzakh region, a list of publications on dissertation topic and species search by ID (Fig. 1.1)

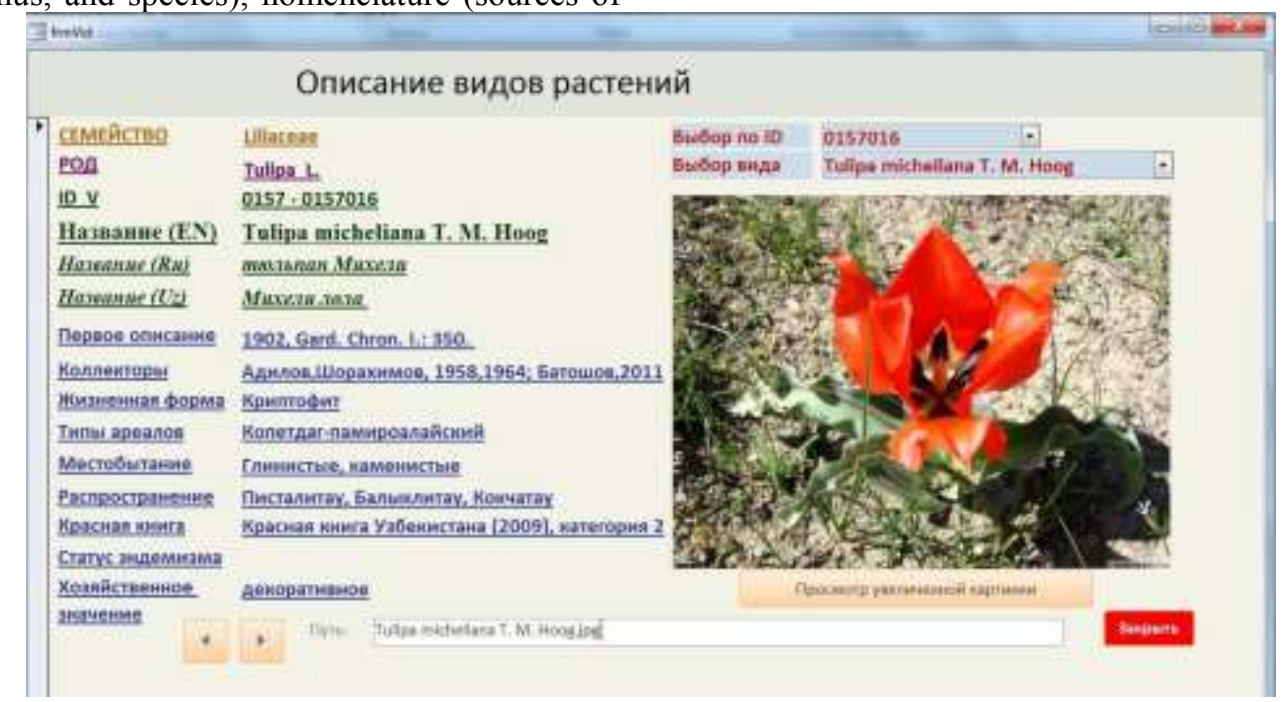

Figure 1.2. Text information for an individual view

For each species geographical coordinates are given in the database (for all herbarium specimens) (Fig. 1.3.). For historical charges, coordinates were primary description), collectors (authors of collection of samples), geography (types of habitats, distribution over the relics of Southeast Kyzylkum), ecology (types of habitats), status endemism and rarity etc. 


\section{EPRA International Journal of Research and Development (IJRD)}

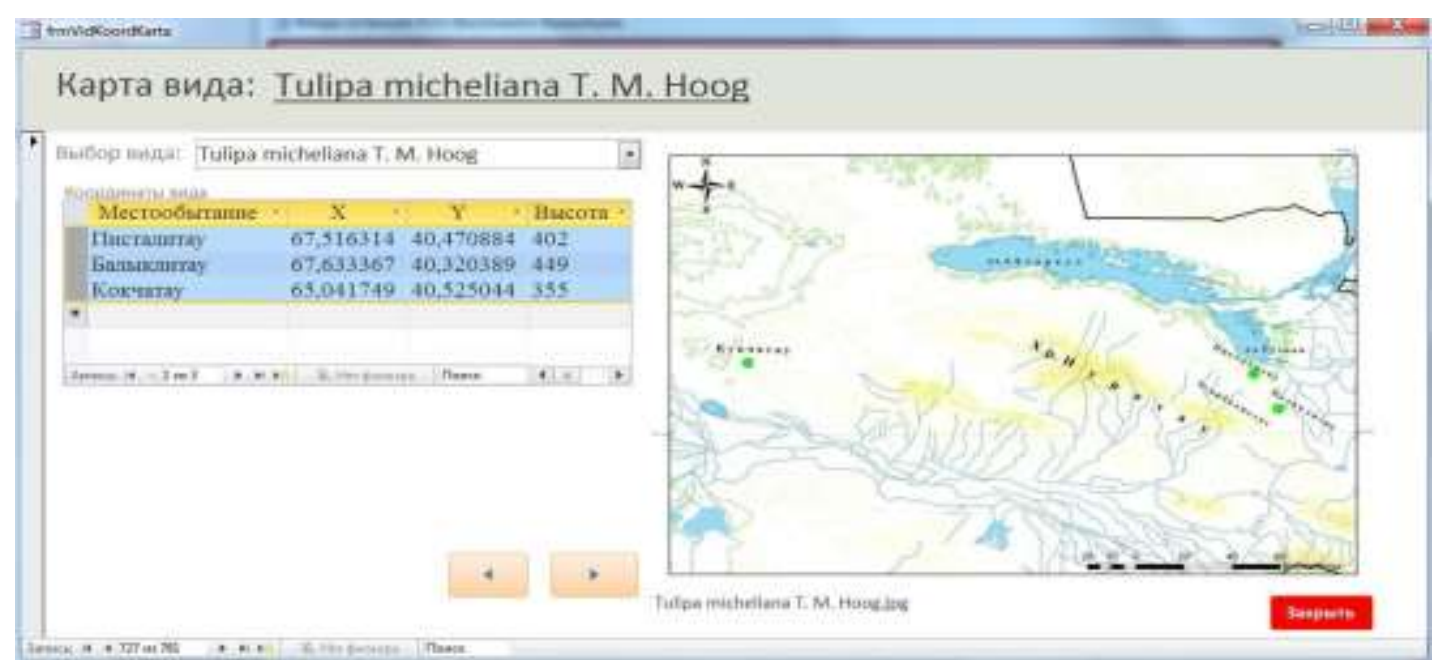

Fig. 1.3. Information on geographical coordinates and species distribution maps

So far as over the past century many toponyms have repeatedly changed, the historical maps from the TASH archives were truly invaluable in this work. The coordinates were entered into the table in Microsoft Excel format, imported into the GIS using the ArcGIS 10.0 program, and saved as vector layers with collection points for herbarium samples (GIS shapefiles). Licensed ArcGIS was obtained through sponsorship of the GEF Small Grants Program. Satellite images from open Internet resources (Google, Yandex, etc.) exported to GIS using the SAS Planet program, as well as vector and raster layers from an open Internet resource (www.naturalearthdata.com). To create view distribution maps from ArcGIS, the data was imported into a jpg image file.

On the basis of the author's data and accumulation of existing material, an electronic database was developed with GIS maps of the distribution of species that has no analogues among the arid mountains of Central Asia.

The database was transferred for practical use to the State Committee for Nature Protection as an information resource for the protection of plant diversity, as well as to the Ministry of Higher and Secondary Education for the preparation of scientific and pedagogical staff and scientific research.

\section{REFERENCES}

1. Batoshov A.R. Flora ostantsov Yugo-Vostochnogo Kyzylkuma elektronnaya baza dannykh. - Tashkent, 2016. Microsoft Access 2010. Svidetel'stvo № BGU 00330.

2. Karimov F.I. Odnodol'nyye geofity Ferganskoy doliny - elektronnaya baza dannykh (po materialam doktorskoy dissertatsii). - Tashkent, 2015. Microsoft Access 2007-2010.

3. Tojibayev K.SH. Flora yugo-zapadnogo Tyan'Shanya (v predelakh respubliki Uzbekistan) Elektronnaya baza dannykh - Tashkent, 2010. Microsoft Access 2007.

4. Tojibayev K.SH., Beshko N.YU., Popov V.A. O proyekte

botaniko-geograficheskogo rayonirovaniya Uzbekistana // Mater. konf. Problemy sokhraneniya bioraznoobraziya. Sbornik stat'yey. - Gulistan: Universitet, 2012. - S. 6-10.

5. www.naturalearthdata.com. 